\title{
NOTA PRELIMINAR
}

\author{
POR \\ EUGENIO CHANG-RODRIGUEZ \\ Queens College of the City University of New York
}

E1 indigenismo, como movimiento ideológico y artístico con el explícito deseo de mejorar la vida del indio en la sociedad, nace en los mismos albores de la Conquista. Así lo evidencia el sermón del dominico fray Antonio de Montesinos de 1511. Una pléyade de escritores y artistas lo hicieron suyo en los siglos siguientes.

Durante el coloniaje, sus mejores manifestaciones se hallan en las epístolas y crónicas. Ahí están para atestiguarlo las de fray Bartolomé de las Casas, Titu Cusi Yupanqui, el Inca Garcilaso de la Vega y Guamán Poma de Ayala. Desde entonces ha florecido periódicamente en las coyunturas de la historia continental. Volvió a brotar en las postrimerías del neoclasicismo y durante la gesta de la revolución por la primera independencia hispanoamericana de principios del siglo pasado. Unas décadas más tarde, durante las crisis de consolidación republicana, se desarrolló con especial tono romántico para dar las obras denominadas indianistas. En los años veinte y treinta de este siglo irrumpió nuevamente por senderos naturalistas, criollistas, neorrealistas y vanguardistas hasta producir obras de gran circulación y muchas traducciones. Huasipungo (1934), de Jorge Icaza, y El mundo es ancho y ajeno (1941), de Ciro Alegría, son sólo dos de sus más divulgados frutos. Entonces el movimiento se nutrió de un fervor socialista, que posee especial originalidad en las contribuciones de José Carlos Mariátegui ${ }^{1}$. Posteriormente, algunos críticos, alucinados por la nueva narrativa y con parámetros extracontinentales y de engañoso universalismo, restaron lucidez y validez al indigenismo. Paradójicamente, lo hicieron en circunstancias en que movimientos ideológicos de reafirmación de la

\footnotetext{
${ }^{1}$ E. Chang-Rodríguez, Poética e ideología en José Carlos Mariátegui (Madrid: Porrúa Turanzas, 1983), pp. 143-182.
} 
identidad nacional y revaloración de lo autóctono contribuían a orientarlo hacia el neoindigenismo. Los rios profundos (1958), de José María Arguedas, y Oficio de tinieblas (1962), de Rosario Castellanos, hacen suyas nuevas corrientes estéticas para expresar con inusitada voz el pensar, el sentir y la visión del autóctono indoamericano, no exteriorizados antes. Mas, al examinar cuidadosamente la vasta producción de estas olas literarias, se hace evidente la heterogeneidad y el carácter pluricultural de la sociedad que la produce. Indianismo, indigenismo y neoindigenismo, como las corrientes negra y negrista ${ }^{2}$, revelan los avatares del proceso histórico y las mutaciones estéticas en Latinoamérica. Dan la impresión de ser manifestaciones de la homogeneización ideológica y artística de los segmentos integrantes del todo pluricultural en trance de mestización y modernidad.

Vale notar que desde su nacimiento, el movimiento ha suscitado álgidas polémicas y apasionados debates. Recuérdese el de los juristas salmantinos Francisco de Vitoria y Juan Ginés de Sepúlveda en el siglo XVI; rememoremos también el sostenido por Julio Cortázar y José María Arguedas hace una veintena de años. Que el interés en el indigenismo no ha caducado ni ha dejado de interesar a la crítica lo prueba este volumen, muestra parcial de otros que podrían editarse. No nos sorprendamos si, a despecho de los anuncios de su agotamiento definitivo, el indigenismo renazca con mayores brillos y nuevos rumbos.

En esta pausa de su flujo y reflujo conviene posar algunas preguntas: ¿Pertenecen al indianismo o al indigenismo los testimonios indígenas de la Conquista y los textos coloniales por cronistas indios y mestizos? ¿Son válidas las categorías usadas desde hace unos cincuenta años? ¿No son los términos indianista, indigenista y neoindigenista más aplicables a la literatura producida en los dos últimos siglos? ¿Por qué se insiste en el inveterado hábito de definir estas categorías? ¿No se suele recurrir a las definiciones y redefiniciones cuando se las pone en tela de juicio? ¿Comienza verdaderamente el llamado indigenismo con Aves sin nido (1889), de Clorinda Matto de Turner, o con Wata Wara (1904), de Alcides Arguedas? ¿Cómo y cuándo debe hacerse el deslinde? Por otra parte, los. textos mismos refutan a José de la Riva Agüero cuando afirma que los indigenistas son necesariamente antihispanistas ${ }^{3}$, y a la vez contradicen a Víctor Andrés Belaúnde cuando sostiene que los indigenistas son agentes de disyunción y ruptura animados por un nacionalismo racial ${ }^{4}$.

${ }^{2}$ E. Chang-Rodríguez, «La poesía negra y la poesía negrista», Memorias del VII Congreso del Instituto de Literatura Iberoamericana (México: 1960), pp. 65-72.

${ }^{3}$ Afirmación del Perú (Lima: Pontificia Universidad Católica del Perú, 1960), I, p. 10 .

${ }^{4}$ La realidad nacional, 4. ${ }^{a}$ ed. (Lima: Banco Internacional del Perú, 1980), p. 33. 
En este número especial de la Revista Iberoamericana reunimos trabajos representativos sobre tan importante corriente de la literatura hispanoamericana. Ellos auscultan y critican con diverso criterio y variada metodología algunas de sus obras representativas. El volumen testimonia la importancia de esta modalidad literaria a la vez que destaca su resonancia y múltiples proyecciones.

Sirva este último párrafo para agradecer a Alfredo A. Roggiano el añadir a los trabajos que solicitamos especialmente para este número algunos artículos pertenecientes a las reservas de la Revista Iberoamericana y por invitarme a colaborar con él en esta empresa editorial. Nuestro agradecimiento a todos los autores cuyos trabajos se incluyen en esta colección. 
